Jens $F$. Jensen

\title{
De Sidste Moderne - de første postmoderne
}

'Tidlig postmodernisme' og tidsskriftet $t a$ '.

Pre-script: - 'Vi befinder os i en situation, hvor manglen på tradition er den nye tradition, vi kan bygge på'. - 'Det traditionelle krav om en stadig fornyelse og fornægtelse af tidligere anvendte kunstneriske former har spillet fallit'. - 'Der er nu mulighed for at vælge frit i dyngen af opbrugte former'. - 'Tiden er sat i stå, hele verden er til disposition', 'alle stilarter og impulser er lige legitime. Ismernes fantastiske borgerkrig'. - 'Jeg eklektiker... Jeg tager andres ting... Jeg benytter mig af materialemylder...' 'Lad os omgås litteraturen med total frivolitet, en depravation så dyb, at alt bliver tilladt og muligt. Alt kan bruges, hvis man kan finde noget at bruge det til'. - 'Hensigten er at tegne omridset af en så rigt facetteret post-modernistisk æstetik som muligt'.

...Udtalelser fra den dagsaktuelle æstetiske debat. Positioner på den samtidige kulturelle scene. Højtprioriterede punkter på den øjeblikkelige postmodernistiske dagsorden. Tilsyneladende.

Jeg har $\mathrm{i}$ en tidligere artikel - -Om postmodernismen er næsten alt allerede sagt fra begyndelsen... " ${ }^{1}$ forsøgt at kortlægge den specielt amerikanske postmodernisme - primært i konteksten af den litterære og kulturelle debat - og dér bl.a. argumenteret for, at 'det postmoderne' og 'postmodernismen' - som termer og fænomener - snarere end i sen-70erne og 80erne fàr deres historiske tilsynekomst i 60erne. Afsøgningen pegede $\mathrm{i}$ forhold til en dansk 60er-sammenhæng på tidsskriftet $t a$ ' som særlig privilegeret udkigspunkt til det omtalte kulturelle og æstetiske ombrud. Og faktisk er den dagsaktuelle $80 \mathrm{er}-$ debat netop kun tilsyneladende fødekilden for ovenstående citatpluk - i realiteten er alle citater taget fra miljøet omkring tresser-tidsskriftet $t a$ '. 


\section{En 'post-modernistisk' estetik-eller: "Der står en hjort ved en skousø".}

Tidsskriftet $t a$ ' udkom med ialt 8 numre fordelt over årgangene 1967 og 1968 og under redaktion af en række kritikere og yngre eksperimenterende kunstnere, der for hovedpartens vedkommende havde debuteret omkring midten af ti-året: Erik Thygesen (ansvarshavende redaktør), Peter Louis-Jensen (kunstredaktør), Hans-Jørgen Nielsen (litterær redaktør), Poul Nielsen (musikredaktør), Kristen Bjørnkjær, Henning Christiansen, Per Kirkeby, Bengt af Klintberg, Jorgen Leth og Vang Lundby, samt fra og med nr. 5 også Stig Brøgger. En redaktion der samtidig udgjorde den relativt faste kreds af bidrag-ydere.

Tidsskriftets erklærede formål - at skabe et miljø hvorindenfor den nye generations holdninger og kunstneriske udtryk kunne fremlægges og gennemprøves - blev allerede fra starten formuleret i direkte polemisk opposition til den indtil dette tidspunkt dominerende modernisme. Den usignerede leder i det første nummer af $t a^{\prime}$ lagde således $\mathrm{i}$ den indledende sætning ud med folgende markering: »Der er de sidste par år sket endnu et opbrud i kunsten. Tiden synes at være løbet fra den såkaldte »modernisme« og dens menneske- og kunstopfattelse« $(1967,1: 1)$. En markering der yderligere blev slået fast som redaktionel linie, da Erik Thygesen i en kommentar til den hidtidige modtagelse af tidsskriftet afsluttede lederen i $t a a^{\prime} 3$ med direkte at pointere: »Hensigten med bladet er den helt enkle: gennem en række numre at tegne omridset af en så rigt facetteret "post-modernistisk " astetik som muligt « (1967,3:3). Hvor begrebet 'postmodernisme' formentlig for forste gang tages i anvendelse på dansk grund. Selv om det også - skal det retfærdigvis siges - er det eneste tilfælde, hvor termen optræder i direkte form i hele tidsskriftets udgivelses-periode.

Det aktuele ombrud mod en 'post-modernistisk' æstetik og en ny kunstnerisk erfaring lader sig til en begyndelse måske tydeligst anskueliggøre inden for musikken som privilegeret domæne Og her via et par fremsynede og foregribende artikler musikkritikeren Poul Nielsen tegner sig for i den første årgang af $t a$ ': »Der står en hjort ved en skovsø - Om Ib Nørholms musik « ${ }^{1}$ og »Figurativ musik «. ${ }^{2}$

I forstnæunte tager Poul Nielsen analytisk afsæt i Ib Nørholms strygekvartet: "Mit grønne Herbarium «, der karakteriseres som 'kalejdoskopisk', som 'attitude-skiftende', som et 'katalog over de virkemidler og materiale-felter, Nørholm har brugt i de skiftende faser i sin produktion« $(1967,1: 5)$. Og selv om Poul Nielsen her godt kan få sig selv til at kalde strygekvartetten »broget... i sine stilistiske virkemidler« (s. 5), så anholder han dog samtidig den nærliggende anmelder- 
floskel: 'stilløshed', idet den ikke synes at give mening appliceret på Nørholms værk. For hvis man blot konstaterer dets stilistiske inhomogenitet - argumenterer Poul Nielsen - så overses pointen: at værket »har en så bred stilistisk referenceramme at det på det nærmeste ophæver begrebet stil i vanlig forstand. At det med andre ord er et dementi af just den opfattelse af begrebet stil, der ligger bag anvendelsen af ordet "stilløshed « (s. 5). Hvor han med stil-konceptet her især sigter til:

"... det konventionelle musikalske stilbegrebs historiske dimension, nemlig opfattelsen af stil som udtryk for en bestemt udviklingshistorisk situation. Stil dermed som noget objektivt historisk forpligtende, stilistisk homogenitet som betingelse for et værks kunstneriske gyldighed. Kort sagt: stilbegrebet som konfiguration af en kunst-darwinisme, der har holdt sig med stædighed $t$ il dato. Stilistiske fænomener betragtes som vertikalt fikserede $i$ en bestemt historisk sammenhængs-kæde.« (s. 5)

Poul Nielsen benytter nu disse refleksioner anstillet i tilknytning til Nørholm-analysen som opspring for et mere generelt opgør med netop denne 'kunst-darwinisme', netop denne forestilling om "nødvendighed som historisk kategori« (s. 5) inden for æstetikken. En opfattelse han samme sted karakteriserer som en »i grunden vulgær form for historisk determinisme« (s. 6) og rubricerer som »et filosofisk anliggende, eller rettere: et historie-filosofisk « (s. 5).

Den hidtidige historiske stil-absolutisme bliver nu afløst af en tvingende erfaring af stilistisk pluralitet. For - fortsætter Poul Nielsen med sin centrale pointe -:

"Flersporetheden i det musikalske reaktionsmønster kan nemlig - ærlig talt - ingen unddrage sig. Den diakrone klassificering af de forskellige stilistiske felter erstattes af en synkron. Begrebet stilfase udskiftes med begrebet stil-lag. Stil opfattes som et konventions-felt, modsvaret af et sæt materialemuligheder, der eksisterer med lige stor samtidighedsvardi. (s. 6)

Hvorfor Nørholms musik netop heller ikke er »tilbageskuende, retrospektiv - men rundskuende.« (s. 6).

I $t a^{\prime} 4$ udbygger Poul Nielsen disse refleksioner under rubrikken »Figurativ musik«. En opsats der former sig som en med ovenstående delvist unisont klingende re-interpretation og re-konstituering af komponisten Igor Strawinsky, som også komponerede på udefra hentede stil-reminicenser og lånte manérer, og derfor af den samlede toneangivende musikkritik blev anklaget for at frembære 'restaurative' - endog 'regressive' - tendenser. Poul Nielsens hovedpointe i denne sammenhæng er nedsættelsen af en afgørende differens mel- 
lem: På den ene side traditionalismen, neoklassicismen som almen strømning og på den anden Strawinskys helt særegne neoklassicistiske variant. Argumentation: Typisk for traditionalismen er at den »komponerer løs på én stor længsel efter fortiden« (s. 16). Hvor Strawinskys musik netop omvent »mens den udfolder sig,... konstant forholder sig reflekteret, påpegende, til sit eget musikalske udsagn« (s. 16). Og kendetegnende for neoklassicismen er, at den i sin kerne bærer en stil-absolutisme der »ligesom søger at sætte parantes om tidens stilistiske pluralisme« (s. 14). Mens Strawinsky netop omvendt »tager... den på sig «. Qua sine »konstante skift,... [sin] flakken frem og tilbage over et kæmpemæssigt stilområde« (s. 14). Og qua sit afkald på 'stil-vilje' til fordel for 'spil med stilen'.

I dette bliver Strawinskys forholdesæt både udslag af og udtryk for en kvalitativ ny kunstnerisk situation og æstetisk erfaring, pointerer Poul Nielsen, der bl.a. - men centralt - manifesterer sig i et samenbrud for den tidligere dominerende traditions-forståelse: den 'kunstdarwinistiske' opfattelse af kunst-historien som en lineært og successivt fremadskridende indre udvikling af stadig innovation. Thi det...

"... traditionelle spændingsforhold mellem tradition og fornyelse [bliver] dubiøst $\mathrm{i}$ en tid, hvor de forskellige musikalske bevidsthedstilstande og reaktionsbaner, i deres udspring tilsyneladende fixeret diakront, eksisterer synkront. Det er en situation som uværgeligt må bringe den skabende musiker på andet skudhold af traditionen, end den traditionelle »inside«-model foreskriver.../ / Hos Strawinsky bliver denne så at sige uhistoriske holdning til traditionen demonstreret i skabende praxis. Man kan sige, at Strawinsky nærmest opererer ud fra et horisontalt rundskuende forhold til den musikalske virkelighed, som udgares af de musikalske konventioner ... Og det vil sige, at al musik fra højklassikken ... til idag... får status af én musikalsk sprogtilstand. « (s. 16)

Hermed bliver også det konventionelle stilbegreb der ligger indlejret i den hidtil herskende historisk-genetiske konception af kunsten underløbet. Til fordel for - hos Strawinsky - »en art manipulering med musikalske stilelementer som gloser« (s. 16). En kunstnerisk fremgangsmåde der i Poul Nielsens læsning også får implikationer for opfattelsen af kunstneren og æuvret. Idet man til eksempel ikke kan sætte Strawinskys "skaben på fællesnævner«: Han kan »ligesom ikke kobles sammen med fiktionen om den centrerede skaberpersonlighed, tro mod sig selv og sine idealer... Det er ... som hans værk falder fra hinanden« (s. 15).

Tilbage i den forste artikel vender Poul Nielsen nu dette opgør frontalt mod den æstetik-teoretiker der mest systematisk har udfoldet en sådan historie-filosofisk tolkning af stil-konceptionen: Theodor W. Adomo. Og netop dén Adorno der i Philosophie der neuen Musik 
affærdigede Strawinskys neoklassicisme med rygdækning i Schönbergs tilsyneladende mere evolutions-logiske serialisme. Hos Poul Nielsen beskrevet som: »Adornos gigantiske forsøg på at bortforklare Strawinsky, bare fordi Schönberg var den sidste komponist, der... inden for et ganske bestemt centraleuropæisk miljø kunne påberåbe sig noget, der lignede en »historisk mission«" (1976, 1:6). En historie-forståelse og en stil-absolutisme Poul Nielsen her direkte kalder 'reaktionær'. Ligesom hele Philosophie der neuen Musik karakteriseres som en »i virkeligheden ... reaktionær filosofi«: »En fantastisk benægtelse af virkeligheden« (s. 6). Så til Adornos kritiske diagnose af den samtidige stilistiske mangfoldighed: "Det nutidige musiksprogs pluralitet, de forskellige former for musikliv (...) er udtryk for forskellige historiske udviklingstrin, som indbyrdes udelukker hinanden, skønt det antagonistiske samfund tvinger dem til samtidighed «. ${ }^{3}$ Dér lyder Poul Nielsens skarpe modreplik: "Negativt postulat - for er det sandt, at de forskellige stillag er så vertikalt rodfæstede, at deres samtidige existens er ensbetydende med indbyrdes dementi? Er det virkelig sandt, at hver eneste tonal vending hos Richard Strauss har været musikalsk løgn, fra det øjeblik Schönberg opløste tonaliteten?«

En adornosk opfattelse Poul Nielsen ser udmønte sig i »en ufattelig firskåret materiale-filosofi som basis for musikalske nyvindinger. Kun én vej står åben: de "nie erhörte Klänge«« (s. 6). Og det er netop i relief af denne materialemæssige rigiditet han ser Nørholms værk (og Strawinskys) fremstå som en mere aktuel og gyldig mulighed. Udslag af en radikal ny æstetisk situation hvor netop: "Tidens musikalske pluralitet accepteres... som frugtbar, flerdimensional operationsbasis...« (s. 6). Og symptom på en radikal ny æstetisk erfaring hvor 'angsten for det velkendte' erstattes af nysgerrighed, appetit, åbenhed $\mathrm{i}$ forhold til kunst $\mathrm{i}$ bred forstand. En ny æstetisk holdning der ikke nødvendigvis resulterer $\mathrm{i}$ fordybelsen i 'det banale' - i de "allzuviel erhörte Klänge«. Men hvor åbenheden og den skærpede sansning af de omgivende æstetiske fænomener transformeres i gestaltningen af en kunst »som er ny«: »Fordi den alligevel har et »Schein des Unbekannten«« (s. 8).

\section{II. 'Det Modernes' historiske granser-eller: "Das Altern der Moderne«.}

Peter Bürger har i sit indlæg til »Adorno-konferenz«i 1983 - altså ca. 15 år efter Poul Nielsens artikler - helt parallelt forsøgt at begribe 
ombruddet i den aktuelle kulturelle situation med udgangspunkt $\mathrm{i}$ Adornos æstetiske teori. Hvad der nu hos Bürger benævnes 'postmodernismen' i samtidig kunst og 'postmoderniteten' og 'det postmoderne' i den nuværende socialitet siges på karakteristisk vis at aftegne sig i relief mod de centrale koncepter om 'det moderne' hos Adorno.

Positionerne i Adornos æstetiske teori turde være velkendte - hvorfor de i denne sammenhæng relevante pointer her kun kort og punktvis skal re-aktiveres: Selve omdrejningspunktet i Adornos modernisme-forståelse udgøres af teoremet om 'det æstetiske materiale-niveau'. Hvor han advokerer den opfattelse at det samtidige samfundsmæssige udviklingsstade så at sige genspejles i det kunstneriske materiale: I og med at kunsten er nedfældet subjektivitet, præget af bevidsthed er den også samfundsmæssigt formidlet og historisk formet. Hvorfor det æstetiske materiale som sedimenteret gehalt altid underjordisk korresponderer til epokens totalitet. Hermed er der etableret en fundamental forbindelse mellem social-historisk epoke og kunstnerisk materiale. Samt en dermed sammenhængende fundamental solidaritet mellem kunstens udvikling og den samfundsmæssige ditto Idet begge nemlig i den adornoske konception adlyder princippet om den fremadskridende rationaliserings-proces, 'moderniseringen'. Heri er rationaliteten samtidig sat som kernebegreb også for den kunstneriske produktions-proces. Kun når kunsten teknisk modsvarer niveauet for de samfundsmæssige produktivkræfters udvikling kan den nemlig - ifølge Adorno - fungere som adækvat erkendelses-instrument og protestpotentiale.

Adornos materiale-begreb gør det således muligt at se det æstetiske materiale som følgende den totale samfundsmæssige udvikling. Men det gør det også samtidig muligt at se det æstetiske materiale som et autonomt område - følgende sin egen indre udviklingslogik, sin egen indlejrede historiske tendens og konsekvens. En historisk nødvendig udviklingsretning, et immanent, irreversibelt 'kunstnerisk fremskridt' - som hos Adorno betones til en grænse hvor der formeligt forekommer at udgå 'fordringer' fra det æstetiske materiale, hvor materialeudviklingen næsten synes underlagt en 'tvang'. Hvorfor kunstneren heller aldrig uafhængigt og frit kan forføje over det, men altid er forpligtet på at indløse dets fordringer om en bestemt videreførelse, at medfuldbyrde dets 'objektive tendens' - vil han skabe en kunst der er sand, autentisk og genuin 'moderne'. Teoremet om en historisk tendens og konsekvens i det æstetiske materiale afsætter således også for kunstneren en standard for hvad der på et givet tidspunkt æstetisk går og ikke går. I Adornos træffende terminologi formuleret som: 'en kanon af forbud'. Ligesom det på den anden side sikrer at man til 
enhver tid kan udpege det sted hvor materiale-niveauet er på sit mest avancerede: 'der fortgeschrittenste Materialestandard der Kunst'. Hos Adorno altid forstået som én »international standard« - i forhold til hvilken alt andet bliver perifert og provinsielt, restaurativt og regressivt. Rimbauds imperativ: »I faut être absolument moderne « bliver af Adorno med andre ord interpreteret som en bestemt forpligtelse over for det fremskredne æstetiske materiale. Hvor det at være på højde med tiden bliver ensbetydende med at drive materialetendensen videre. Resulterende i en koncept om modernismen hvor denne fundamentalt bliver bestemt af tanken om nødvendig udvikling, om æstetisk fremskridt som fuldbyrdelsen af en historisk proces. Samt bliver underlagt en konstant innovations-tvang, et vedblivende krav om at være 'på niveau med tiden', 'at gøre det nye', 'at gå foran' i en - med Harold Rosenbergs ord - 'Tradition of the New'. Hvor forpligtelsen på traditionen karakteristisk manifesterer sig negativt: som kravet om fornyelser og brud. En fortløbende emancipation fra alle traditionelle materialer og forudgivne formkategorier.

Som konsekvens af dette teorem om 'der fortgeschrittenste Materialstandard der Kunst' kan Adorno i en given periode også kun anerkende én materialestandard, ét æstetisk materiale som det mest avancerede. Ligesom han følgelig også må opfatte den modernistiske kunsthistorie som én lineær og monolitisk historie. Modsat medfører den énstrengede materiale-filosofi at Adorno konsekvent må afvise ethvert tilbagegreb til forudgivne former, enhver genoptagelse af traditionelle stile, ethvert forbrug af overleveret materiale. Både neoklassicismen og avantgarden - i dennes specielt 'avantgardistiske' omgang med det forudgivne i f.eks. collagen og montagen - bliver således og af samme grunde - sat uden for Adornos begreb om 'det moderne'.

Det er hele dette kompleks af teser og teoremer i Adornos teori om 'det moderne' der ifølge Bürger underløbes i den samtidige kulturelle situation. Alt hvad Adornos æstetiske teori implicerer synes den samtidige postmoderne æstetiske erfaring nemlig at dementere: Der er ikke længere nogen 'Kanon der Verbote', tværtimod synes alt nu tilladt og ingen materialer belagt med tabuering. Der bliver tilmed tale om udviskningen af $\gg .$. den stive dikotomi mellem 'høj'- og 'lav'-kultur, som endnu for Adorno stod i et uforsonligt modsætningsforhold « (1983:178). Det er ikke længere muligt med nogen overbevisning at udpege »et bestemt materiale som det historisk mest avancerede« (s. 190) - tværtimod er situationen kendetegnet af et 'Materialvielfalt', en »forvirrende sideordning af det forskelligartede« (s. 190) der indicerer »(die) freie Verfügung über verschiedene Materialstünde« (s. 191). Der er ikke længere nedlagt en historisk tendens i ng 
der udgår ikke længere imperativer fra materialet - tværtimod synes alt at bevæge sig i samtlige retninger samtidig. Hvorved også forestillingen om en klar udviklingslogik og en lineær, monolitisk historie bryder sammen. Der eksisterer ikke længere nogen ubetinget tillid til en indre konstitutiv korrespondence mellem kunstnerisk materiale og socialhistorisk epoke - denne konception afslører tværtimod i stedet sin i sidste instans historie-filosofiske fundering som idag har mistet meget af sin tidligere tiltrækningskraft. Og endelig er der ikke længere nogen større tiltro til en fremadskridende rationalisering, endmindre forhåbninger om en til sin afslutning fuldbrydet rationaliserings- og moderniseringsproces - tværtimod blotter dette forestillingskompleks sig nu i sine fundamentalt totaliserende og centraliserende, etnocentristiske og endog terroristiske gester.

Efter sammenbruddet af de adornoske absolutter som 'det moderne' kan Bürger derfor - og her netop mod Adorno - indkredse kernen i den samtidige - og nu altså 'post-moderne' - æstetiske erfaring som: "... der gives intet mest avanceret materiale, alle historiske materialetilstande er på samme måde forføjbare for kunstneren« (s. 190).

Bürger vælger at begribe dette ombrud i modellen og under essaytitlen af: »Das Altern der Moderne «. ${ }^{2}$ Dvs. mindre som en overgang til en radikalt ny fase 'efter modernismen' end som en indre udmattelse og 'forældelse' af centrale impulser i 'det moderne' selv. I erkendelsen af at kunstens udvikling i visse tilfælde kan støde mod nogle i selve 'det moderne' immanent liggende grænser. Her primært i forhold til: Den fremadskridende tendens mod 'total rationalisering'. Den tiltagende reduktion af 'jeg-udtryk' og individualitet. Den stadige innovation og konsekvente videreudvikling af det kunstneriske materiale. Bevægelser der alle synes at kunne udtømmes. Og som heri afsætter krav om kvalitativt nye kunstneriske forholdesæt. Det er alt dette - sammen med en tiltagende tendens i retning af 'modernistisk konformisme' - Bürger opsamler i kategorien: 'Das Altern der Moderne'. En art 'sen moderne' indsigt der samtidig får virkning med tilbagevirkende kraft i forhold til den hidtidigt kanoniserede historie-forståelse og traditions-konstruktion: "Das Altern der Moderme lader ensidigheden i en traditions-konstruktion komme til syne, som i musikken kun anerkender Schönbergskolen og i den fortællende litteratur kun fă forfattere som Proust, Kafka, Joyce og Beckett.« (s. 190)

Hvad Bürgers analyse på særlig fordelagtig vis anskueliggør er: at det samtidige såkaldt '.postmodernistiske' opbrud både kan begribes som noget radikalt 'andet' hinsides modernismen og som selve modernismens kommen-til-bevidsthed om sine egne historiske grænser; og at disse historiske grænser snarere end at være grænserne for 
modernismen som sådan er de historiske grænser for Adornos på teoremet om det 'avancerede materiale-niveau' baserede koncept om 'det moderne'.

\section{La querelle des anciens et des modernes - eller: "Why not?"}

Disse primært musik-filosofisk funderede overvejelser omkring et epokalt ombrud i den kunstneriske situation og æstetiske erfaring som altså allerede Poul Nielsen i sen-60erne var i stand til at tage de forste præcise seismografiske målinger på - lader sig imidlertid ikke indhegne som en isoleret musik-æstetisk problematik. Blot er musikken i denne sammenhæng valgt som ansats fordi præcis dette område særlig tydeligt lader det aktuelle problemfelt komme til syne. Men det registrerede ombrud finder sine korrespondenser i hele feltet for den æstetiske erfaring. I 'lav'-kulturen såvel som i hovedparten af 'høj'kulturens kunstarter, litteraturen, poesien inklusive.

Tilmed bliver spørgsmålet om hvad der inden for litteraturen på et givet tidspunkt går og ikke går gjort til genstand for en mindre poetikpolemik der på anskuelig vis gestalter de to i det foregående opridsede positioner: den 'modernistiske' - og den 'efter-modernistiske'. Hvor den første indtages af Per Højholt, og den anden repræsenteres af henholdsvis Per Kirkeby og Hans-Jorgen Nielsen. En polemik der selv om den ikke forløber i $t a$ 's spalter - men derimod i en af aflæggerne af $t a$ ': nemlig $M a k^{l}$ - allegevel forbinder sig til den problematik tidsskriftet $t a$ ' havde sat i centret af den kulturelle debat.

Per Kirkeby havde allerede i 1968 i Billedforklaringer manifestagtigt erklæret sig for eklekticisme, for æstetiske lån og for genbrug af overleverede former og foreliggende materiale. Og her vel at mærke ikke kun som maler, men også som forfatter. Kirkeby havde proklameret:

\footnotetext{
》Jeg er eklektiker. Manifest. / Jeg tager andres ting - i videste forstand. Jeg benytter mig af materialemylder... Jeg plukker ud og samler - og udvælger. Mit system, der er et ægte system, konstitueres af private forkærligheder og kuriosumagtige særinteresser og $\mathrm{i}$ hvert tilfælde noget mystisk. Jeg er romantisk og aristokratisk. Min kunst handler om kunst. Jeg skriver og maler på samme måde... «²
}

Og Hans-Jørgen Nielsen havde tilsvarende i 1968 i Vindrosen-artiklen: "Mere end tre ting jeg ved om systemdigtningen « argumenteret for en udvikling bort fra den mere formalistiske systemdigtning der betjente sig af spilleregler - efter at disse »havde udtømt sig selv«. En 
muligheds-udtømning som havde tilvejebragt en indsigt i, skrev han, at »en hvilken som helst stil kan anvendes systemisk«. Og en indre udmattelse hinsides hvilken der angiveligt var afsat en helt ny æstetisk situation, hvor det mindre handlede om overholdelse af stive systemer og imperativer om bestemte procedures og formers nødvendighed, end om erkendelsen af at "det er anvendelsen af former... der er afgørende« (s. 76). Hvorfor både de 'traditionelle' og de 'nye' herefter stod til disposition.

Per Højholts Mak-opsats: »Intethedens grimasser« udfolder sig som et polemisk angreb på præcis disse to citerede positioner i den samtidige litteratur. Estetiske konceptioner Højholt med jævne mellemrum registrerer dukke op hos en del forfattere $\mathrm{i}$ "generationen omkring Eksempler/ta'/Mak« (1969:27). Højholts egen holdning til modernistisk æstetisk, tradition og kunstnerisk eksperiment og materiale - som den fremstår her samt i den lidt mindre kryptisk formulerede artikel »Tradition og Experiment « fra $t a$ ' 3 - er at »ethvert modernistisk kunstværk må hævde og demonstrere sin status som experiment for overhovedet at være gyldigt som henvendelse" (1967,3:28). Hvor eksperiment i denne sammenhæng helt specifikt refererer til at kunstneren "henter sin erfaring gennem forsøg med materialet« (s. 28). Hvilket igen vil sige at følge materialets »responsum som altid vil påkalde det ubestemte i det bestemte, det grænseløse i det begrænsede... (s. 29). Og dette poetisk skabende arbejde med materialets responsum og imperativer vil altid - i henhold til Højholt - have traditionen både som forudsætning og som resultat. Hvorfor: »Kun den kunstner der har et bevidst forhold til traditionen kan afstedkomme experimenter « (s. 27). Hos Højholt lokaliseres altså på dette tidspunkt en variant af den kendte modernistiske forestilling om en i materialet iboende tendens og konsekvens. Som kunstneren nødvendigvis må følge - skal der skabes noget æstetisk gyldigt. Samt en opfattelse af forpligtelsen på traditionen, hvor den typisk ytrer sig negativt: som kravet om eksperimentelt at bryde af mod det nye.

Højholts kerne-kritik af Kirkeby rammer netop dette materialepunkt: at han i sine sprogligt-litterære arbejder benytter sig af ekstralitterære systemer, dvs. systemer hentet uden for det traditionelle litterære materiale-felt. Uden han deri formår at etablere forbindelsen mellem disse ekstra-litterære systemer og de sprogligt-litterære regler og fremtrædelsesformer man trods alt ikke kan undgå at forholde sig til - vil man formulere sig sprogligt. Derved kommer Kirkeby til at »savne litterære kriterier for den systemiske styring «, for den »sproglige manipulering «. Og kan således heller ikke indløse de krav der ligger i materialet. Hvilket ytrer sig i 'manglende radikalitet', 
'konventionalitet', at hans litterære værker »ikke afviger nævneværdigt fra den »traditionelle« modernismes digtere« (s. 36). I Højholts konception falder Kirkeby med andre ord bag om den af materialet givne standard, under det af traditionen givne niveau.

Højholts hovedanke mod Nielsen er både enslydende og modsatrettet. Enslydende fordi også Nielsen anklages for 'manglende radikalitet', manglende forpligtelse på 'det nye'. Modsatrettet fordi Nielsen i kontrast til Kirkeby faktisk benytter sig af eksklusivt litterært sprogligt materiale og på en bevidst måde opererer inden for en litterær tradition. Og i dette netop omvendt anklages for at henvise til 'litterære systemer'. Men her fordi disse er »traditionelle, i.e. existerer i forvejen « (s. 26). Hvad Nielsen med andre ord stilles til doms for er at tillade - og sidestille - anvendelsen af 'traditionelle' og 'nye' former. Højholts mest substantielle indvending er at enhver traditionel dvs. given, overleveret, eventuelt forældet form nødvendigvis dels vil have indlejret »så kraftige tilbøjeligheder til at gestalte historier, fyldte forløb, kadencer, hovedtemaer, klimakser og pointer...« (s. 27). Og dels vil være belastet af henvisninger til andre epoker og de dermed sammenhørende samfundsrelationer, verdensopfattelser, menneskesyn. Tilbøjeligheder og henvisninger der altid vil være ufrivillige og irrelevante og hvis eneste funktion er at »imødekomme eventuelle nostalgiske behov« (s. 27). Netop spørgsmålet om muligheden af at ned-nivellere, rense eller 'tømme' disse overleverede former for formelle betingelser og indfældede betydningslag så en systemisk anvendelse kan foregå 'rent' synes her at være altafgørende: »Hans-Jørgen Nielsen mener de kan opleves som tomme, jeg mener ikke de kan « (s. 27), fastslår Højholt, og advokerer derfor i stedet det konsekvente og forpligtende arbejde med radikalt 'nye former'.

Hos Højholt inkarneres således på dette historiske tidspunkt en bestemt udgave af den 'traditionelle' eller 'gammel-modernistiske' holdning: Konfronteret med Kirkebys urene, hybride, grænseoverskridende eksperimenter med litteraturen søger han at redde de specifikke litterære kvaliteter og bevare forpligtelsen på det særlige sproglige materiale-niveau. Og sat over for Nielsens hæudelse af en mulig sideordning af eksperimenter med 'traditionelle' og 'nye' former forsøger han at fastholde forståelsen af 'eksperimentet' og 'nydannelsen' som identisk med 'innovative former', skabt af kunstneren selv i og med det pågældende værk, dvs. inden for rammerne af den velkendte modernistiske formnominalisme.

Hans-Jørgen Nielsens respons på Højholts kritik bringes i samme nummer af Mak. Under rubrik-spørgsmålet: »Why not?« går Nielsen her til frontalt modangreb mod hvad han ser som Højholts 
'absolutisme', 'normativitet', 'grænsesætten' og - som det direkte hedder - »purt konventionelle regler for hvad der er "materialerigtig «, litterær og sproglig litteratur« (s. 28). Af Nielsen - i denne sammenhæng - sigende beskrevet som en vrimmel af "absolutte imperativer om, hvad man ikke kan og ikke må...« (s. 28), som selvbestaltede konventioner manifesterende sig i »alle disse små »adgang forbudt«-skilte« (s. 29). Nielsen diagnosticerer den højholtske holdning som en art naiv kunst-uskyld, som en »forældet og provinsiel opfattelse af begreber som "form«, "eksperiment«, "litterært« og »traditon«« (s. 28). Og - fortsættes der med en lige så sigende formulering: Højholt...

\footnotetext{
»...mangler at få taget nogle mødomme.../ /... Han tror endnu der er grænser, og opsøger dem normativt, hvor den unge generations eksperimenter bygger på en stadig grænseoverskridning, en særlig why not?-holdning, som de siger i Amerika.« (s. 28)
}

En strid - altså - mellem på den ene side: forpligtelsen på at føre kunstens historiske materiale-niveau videre, og på den anden: En mulig ny forføjbarhed over alle overleverede og også 'kunst-eksterne' materialer og procedurer - i en ny »Why not? «-disponibilitet.

I denne poetik-polemik tegner der sig således samtidig en miniature en art moderne gennemspilning af 'la querrelle des anciens et des modernes': den århundrede-gamle strid om det æstetisk mulige og nødvendige mellem traditions-fastholdere og traditions-udbrydere. Eller måske netop en art postmoderne gennemspilning: den samtidige strid mellem 'de moderne' og 'de post-moderne'. Og her en postmoderne gennemspilning $i$ en langt mere dybtgribende betydning også. For som det er blevet antydet $\mathrm{og}$ vil blive mere åbenlyst længere fremme, să har den traditionelle orientering i denne terminologiske opposition mellem 'anciens' og 'modernes', der ellers har været paradigmatisk i netop - moderne tid, nu tydeligvis skiftet valører. Hvor de sidst-tilkomne og sidst-placerede i oppositionen indtil nu nemlig fundamentalt har været solidariske med: den lineære, irreversible historiske tidsforståelse, udviklingsidéen og fremskridts-doktrinen, rationaliseringsog moderniseringsprocessen, dér er denne solidaritet nu flyttet til den første del af oppositionen. Eller hurtigere: Hvor de første altid har kigget tilbage og de sidste frem, dér er det nu diamentralt modsat: De første kigger frem. De sidste tilbage. Også deri ligger indicier for at vi nu er 'efter det moderne'. I et 'efter-moderne' spil. I en 'efter-moderne' tid. 


\section{Den tabte uskyld-eller: "Omkring Zero"}

Dette brud-billede er væsentligst taget i den synkrone dimension. Som to samtidige - hinanden gensidigt profilerende - positioner på den samme problematik. Opbruddet i den kunstneriske situation og æstetiske erfaring lader sig imidlertid også affotografere i den diakrone dimension. I et tidsmæssigt perspektiv, et historisk forløb. Og også her synes tidsskriftet $t a$ ' at udgøre et særligt privilegeret udkigspunkt til brudfladens geologi.

Den nye astetiske sensibilitet og kunstneriske materiale-holdning der kendetegner gruppen omkring $t a$ ' bliver måske mest præcist tegnet af Hans-Jørgen Nielsen når han allerede i sin spids-artikel i $t a$ ' 1: »What's happening, Baby'« giver følgende på én gang programmatiske og deskriptive signalement af de samtidige kunstneriske fænomener: »Afpersonalisering, anonymitet, mekanik, materialefremmende spilleregler, formskabeloner, fladhed, monotoni, sideordning i stedet for over- og underordning " $(1967,1$ s. 2). Termer der alle siges at have affinitet til en lang række aktuelle aktiviteter inden for et bredt spekter af kunstarter - herunder også »konkret poesi og lignende litterære udtryk«. Læst på bagtæppet af den hidtidige modernisme - og her specielt dennes karakteristiske erobring af objektet, personlighedens invadering af det æstetiske materiale med subjektiv, human betydning, fremtræder $t a$ '-gruppens materiale-holdning og æstetiske tendens således primært - og centralt - som: en voldsom nedskrivning af det subjektive, personlige udtryk; en »radikal nedkøling, en bevidst og rationel reduktion af alle emotionelle ladninger«. Som det hedder med en typisk formulering fra Nielsens introduktion til den nye digtning i Vindrosens konkretist-nummer i 1966. ${ }^{1}$ En æstetisk bestræbelse der iøvrigt helt tilsvarer den måde hvorpå John Cage i sin bog Silence havde opfordret komponisten til at "give up the desire to control sounds, clear his mind of music... and set about discovering means to let sounds be themselves rather than vehicles for man-made theories or expressions of human sentiments « (1961:10).

Det er på denne baggrund - skriver Nielsen tilbage i den førstnævnte artikel - at »man må forstå den nye kunsts allergi over for udtryksattituder af den nativt subjektive, inderlige art. Disse attituder har i deres bevidste eller ubevidste patos nemlig ikke gennemskuet deres egen karakter af attitude, hvorved de uanset kvalitet kommer til at virke urimelige og let får et komisk skær. Det historiske reflektionsniveau er nu så højt, at al uskyld er gået fløjten « $(1967,1: 4)$. Og da kunsten således har »mistet den uskyld der skal til for at vælge 
naivt « som det hedder et andet sted, så bliver mere objektivt satte styrende principer "aktuelle som artikulationsmuligheder hinsides den naive subjektivitet« (1967,2:1). Det mulighedsfelt hinsides subjektivismen der her primært sigtes til har affinitet til begreber som: spilleregler, spilsystemer, konceptual kunst, kypernetisk kunst, datamat-kunst, systemdigtning, konkretpoesi. Kunstneriske fremgangsmåder hvor bearbejdningen af det æastetiske materiale som tendens objektiviseres idet kunstneren bliver del af en større selvbevægende maskine. "I want to be a mashine" skal kunstneren - i Andy Warhols skikkelse - have sagt.

Modernismens udbredte ekspressivitet og følelsesfulde jegudtryk fortrænges således af rene materiale-betragtninger. Af en ny afspændt, nøgtern, objektiv attitude rettet mod bearbejdningen af konkret materiale. Hvilket bl.a. manifesterer sig i vidtdrevne reduktioner af de 'naturlige former' - mod mere simple og saglige, klare og kølige strukturer. Så hvor Boulez's diktum: »Man må acceptere kompleksiteten« kunne sættes som paradigmatisk for den tidligere modernisme, dér kan Nielsen som aksiom for den modsatte fordring, den nye kunst stiller, polemisk returnerer: »Man må acceptere simpliciteten $\kappa^{2}$

Denne første karakteristiske tendens i det kunstneriske materiale kan beskrives som en vertikal nedskrivning, en radikal reduktion. Samtidig er der imidlertid også tale om en anden dominerende bevægelse, som er delvist modsatrettet. Og som i relief af den første kan formuleres som en horisontal åbning: En radikal udvidelse af det æstetisk mulige. En nivellering af det kunstneriske materiale. Til en grænse hvor tilfældige virkelighedsudsnit - i traditionen fra Duchamps 'ready mades' - udråbes til kunst: »Udgangspunktet for centrale dele af kunsten idag er en zero-situation «, skriver Nielsen i en enquete til Allan Karprowes essay: »Kommunikations-programmering «: "Kunstbegrebet drevet derud hvor alt kan opleves som... kunst« $(1967,1: 19)$. En æstetisk impuls der imidlertid også i dette tilfælde til dels kan forstås som en reaktion mod det personligt ekspressive, den subjektivistiske invadering af omverden. Således taler Nielsen f.eks. et andet sted om en 'nulpunkts situation', hvor »... »kunsten« altså delvist forkastes til fordel for »virkeligheden « for ligesom at undvige det subjektive ved selve kunstbegrebet ${ }^{3}{ }^{3}$

Begge udviklings-retninger: Den radikale horisontale udvidelse af det æstetiske materiale efter model af Duchamps 'ready mades', og den radikale vertikale nedskrivning af materialet folgende Cages imperativ om at lade 'sounds be themselves' peger imidlertid på en kunstens zero-situation. Kunsten nivelleret ned hvor alt kan erklæres for kunst. 
Kunsten reduceret ned hvor den bliver ren, konkret struktur. Kunsten som alt eller intet.

Den æstetiske kerne-problematik i tidsskriftet $t a$ ' synes dog som en vigtig pointe primært at udkrystaliseres omkring et punkt der befinder sig hinsides denne zero-situation. Således kunne Nielsen allerede i 1965 i en artikel der bar den sigende titel: "Efter Zero« på vegne af komponisten Henning Christiansens musikalske udvikling anstille følgende refleksion: at denne 'nulpunkts-position' »viste sig... at være uholdbar i længden. Man kan godt udnævne hvad som helst til kunst, men heraf følger ikke, at alt bliver lige væsentlig kunst./ Der måtte kunne skabes en mere artikuleret formverden uden derved at forråde den etik, som dikteres af den tilgrundliggende skepsis mod subjektivismen. En formverden efter zero « (1965,7:213). Og i enqueten i ta' l lyder det helt samstemmende: "Efter tavlen er visket ren, er det snarere relevant at diskutere mulighederne for en ny kunst, der har indoptaget zero-erfaringerne som en truisme... Problemet er da hvilken kommunikation... der er mulig uden at forråde zero-erfaringerne, nu hvor en tilbagevenden til den tabte kunstuskyld synes umulig“ (1967,1:19).

Et problem for den nye æstetiske erfaring Peter Louis-Jensen helt uafhængigt i opsatsen "Omkring zero« i samme nummer af $t a$ ' skitserer en mulig løsning på - og opridser den historiske baggrund for. Louis-Jensen tager her netop udgangspunkt i tendensen i den samtidige restetik til wat viske kunstens tavle ren«. Som bl.a. giver sig udslag i en beskæftigelse med selve formernes eksistens - fremfor en fordybelse i deres eventuelle implikationer og indhold. Og fortsætter med at anskueliggøre hvordan det er den successive nedskrivning af disse former der i sidste instans har muliggjort en ny frilægning af materialet på den anden side zero:

\footnotetext{
»Denne tilsyneladende frihed i valget af former skal ses på baggrund af de sidste treshalvfjerds års kunst, der ... har været én lang formreduktion. Lag efter lag er skrællet fri af den klassiske formopfattelse, gennemarbejdet, hvorefter materialet er kasseret, opbrugt. Det er denne proces, der i det store hele er bragt til ende, der giver mulighed for frit at vælge $i$ dyngen af opbrugte former, i erkendelsen af at ingen af disse former længere fører et værdiladet indhold, der alene kan anskueliggøre kunstneriske intentioner.« $(1967,1: 12)$
}

Når Nielsen taler om at kunsten har 'mistet den uskyld, der skal til for at vælge naivt', og at 'det historiske refleksionsniveau nu er så højt at al uskyld er gået fløjten', så har denne 'tabte uskyld' derfor endnu en side. Ud over det omtalte tab af de naivt subjektive, spontant følelsesmæssige udtryksattituder. Nemlig en tabt uskyld - som det 
bl.a. antydes $\mathrm{i}$ »Efter zero« - i forhold til 'bestemte formkonventioner' og til 'kunsten' i det hele taget'. En uskyld som netop gennembrydes i selve zero-situationen. Hinsides hvilken valget af former ikke længere omgærdes af den fundamentale 'naturlighed', sikkerhed og uberørthed der ellers lå i det 'historisk nødvendige'. Og hinsides hvilken valget af stil ikke længere per automatik stiller garantier om renhed via imperativistiske forbud og fordringer om overholdelse af bestemte konventioner og fremgangsmåder. Selve denne forestilling om defloreringen af den æstetiske valgsituation i den aktuelle kunstneriske udfoldelse synes i det hele taget at placere sig centralt for den nye æstetiske erfaring i og omkring tidsskriftet $t a$ '. Per Kirkeby taler således i sine "Modeller « i ta' l helt samstemmende om at kunstnerens æstetiske valg hidtil ofte har været:

"...emotionelt: dette ser mit opladte øje og dette nedfælder min stemningsbă̊rne hånd. Og sådan tegner man med unge bløde fingre, impulsivt, $\mathrm{i}$ uskyldsperioder før valgmulighederne og spillereglernes tilflugt... Når uskylden er opbrugt står jeg med valget hver gang,... Da er jeg også fortabt thi hvad betyder noget. Intet, så jeg opretter mit eget lille tegnsystem.« $(1967,1: 20)$

Hvad Kirkeby i ta' 2 iøvrigt opsamler i tesen: "...enhver tegning er en valgsituation hos den deflorerede kunstner « $(1967,2: 20){ }^{4}$

Via denne konfrontations-collage af citater skulle det tegne sig: Hvad der på den ene side er den radikale vertikale nedskrivning af materialet, den totale reduktion af det æstetiske udtryk. Og på den anden side er den radikale horisontale udvidelse af det æstetisk mulige, den totale nivellering af kunsten. Begge tendenser, der kendetegner kunsten i 60erne, bl.a. omkring tidsskriftet $t a$ ' er at opfatte som to sider af samme sag. Idet begge peger frem mod og ramler sammen $i$ en æstetisk 'zero'-situation. Kunstens 'tabula rasa'. Endvidere skulle det blive synligt: Hvad der på den ene side er denne det restetiske materiales radikale nedskrivning og radikale udvidelse på den anden dén frilægning af det æstetiske materiale og dén frie disponering af traditionens alle former og udtryk, der har kendetegnet kunsten fra sen-60erne over 70erne frem til 80erne. Disse to æstetiske tendenser fremstår - på trods af deres umiddelbare forskelligartethed og uforenelighed - under denne konfrontation og synsvinkling som sammenhængende. Som to sider af samme mønt. Der er den eneste kurante for fremtiden. Hvor den hemmelige udveksling netop udgøres af dén 'zero'-situation hvor nedskrivningen og nivelleringen af materialet samtidig åbenbarer sig som en frilægning af det. Og dette forvandlingspunkt kan samtidig sættes som motiveret cæsur for overgangen 
mellem modernisme og postmodernisme. Det er præcis i dén forstand det giver mening at tale om 'efter-modernisme' i forbindelse med sen60 ernes eksperimenterende kunst og tidsskriftet $t a$ '.

\section{Sammenskreddet for 'høj'-/'lav'-kultur hierarkiet - Eller: "Aberne i Jerusalem Zoo«.}

Frilægningen af det kunstneriske materiale og udvidelsen af det æstetisk mulige betyder også en åbning ud mod det populær-, trivial- og massekulturelle felt. Der ellers siden modernismen og Adorno havde stået som selve emblemet på det inautentiske, uudviklede eller degraderede i kulturen. Og som derfor var behængt med de overhovedet strengeste 'adgang forbudt'-skilte. Allerede i lederen til $t a$ ' l blev den nye kunstner- og kritiker-generation således rammemæsigt indkredset ved »interessen for de populære, folkelige fænomener - triviallitteraturen, fjernsynet, moden, pigtrådsmusikken, massemedierne i det hele taget « (1967,1:1). En åbning og en udvidelse af interessefeltet der også i dette tilfælde polemisk formuleres op mod de i den hidtidige kulturdebat dominerende mondernistiske og nyradikale positioner med de kritiske og totalavisende holdninger til den moderne massekultur, som disse bl.a. havde ytret sig i den såkaldte 'pop-debat' tidligere $\mathrm{i}$ tiåret. Polemiske undertoner der f.eks. kan aflyttes når samme leder fortsætter: »At trække alt for skarpe skel mellem finkultur og massekultur forekommer hverken særlig demokratisk eller realistisk. $t a$ ' vil derfor helt sideordnet beskæftige sig både med musik, litteratur, billedkunst, blandformer samt populære fænomener« $(1967,1: 1)$.

Den nye forsonlige holdning til massekulturen er traditionelt blevet læst som udtryk for en mere umiddelbar accept af og en mere indladende attitude til 'den nye virkelighed'. Der igen kan ses at reflektere det nye velfærdssamfund og en ny forbrugsmoral. Eller den er blevet tolket som udslag af den nye kunstner-generations overvejende ikkeakademiske baggrunde. Der skulle implicere at massekulturen allerede i opvæksten har indgået som integral og intim del af erfaringsballasten. Begge læsninger, der altså udelukkende fokuserer konsumaspektet har uden tvivl noget for sig. Men udover at de kun har øje for det ene aspekt af kunstforholdet, udover at de hermed i princippet kommer til at operere ud fra den samme absolutte modstilling mellem 'høj'- og 'lav'-kultur, som de behandlede fænomener netop tende- 
rer mod at nedbryde og overskride, så overser de i det mindste et par pointer.

Det nye forhold til massekulturen făr et af sine måske mest udtalte udtryk i Erik Thygesens tekst-montage i ta' 3: 'Aberne i Jerusalem Zoo«, der ud fra en rakke forskellige tilgangsvinkler netop tematiserer forholdet mellem 'fin'- og 'masse'-kultur. Thygesen kommer her specielt ind på de vurderingskriterier de to kulturformer traditionelt har været underkastet: "Nok kan kulturelle manifestationer - på baggrund af oplagstal/tilstrømning/publicity/niveau/pris - opdeles i finkultur/massekultur, men i bedømmelsen/oplevelsen/tilegnelsen/ aflæsningen af enkelt-værkerne/-fænomenerne er disse forhold underordnede« $(1967,3: 6)$. Og han peger som positiv model i stedet på følgende nye forholdesæt:

"... at finde planet: OPGAVEN:

1) at anerkende at flower power/Petter Dass/fremmedgørelse/Fanta/Paco Rabanne/ J. Th. Lundbye kan være god/dårlig, men ikke nødvendigvis er det på grund af deres historiske produktionsmassige/geografiske/sociale placering i forskellige mønstre;

2) At koncentrere sig om aflasnings-emnet/-fænomenet, søge at definere det, lade kriterierne vokse frem som et resultat af denne proces;

3) At komme ud over den litterære værdiskala der indtil nu har været tillagt gyldighed også for alitterære emner/fænomener - TV, forbrugeroplysning, narkotika, reklame- og salgsteknik, prævention, billedkunst« $(1967,3: 80)$.

Collage-opsatsens polemiske pointe peger således på et skift i kultursyn. Fra de absolutistiske æstetiske kvalitetskriterier, De facto: de finkulturelle og 'litterære', til de mere relativistisk satte værdisæt med begrænsede gyldighedsområder. Og opløsningen af værdiabsolutismen og den hovedsagelig i valuative termer konciperede modstilling af 'fin'- og 'masse'-kultur står her blot som et særligt illustrativt eksempel på den almene relativering af den æstetiske erfaring og den generelle nedbrydning af kultur- og genreskel der som helhed kendetegner miljøet omkring tidskriftet $t a$ '. Nielsen et sted: »En fælles, alment forpligtende kanon mangler. De gamle genrer befinder sig i mere eller mindre opløst forfatning «. ${ }^{1}$ Nielsen et andet sted: »Elitekultur og massekultur: 'Fri kunst' og 'kommerciel design'. Distinktioner af den art føles efterhånden mere og mere urimelige. I hvert fald så længe de bruges værdiladet «. ${ }^{2}$ I dette perspektiv kan hele Nielsens essaysamling Nielsen og den hvide verden således ses som et forsøg på at etablere nye relativistiske vurderingskriterier i aflæsningen af kulturelle fænomener. Hvorunder de tidligere, absolut fastlagte, perspektivistiske og vertikale værdi-hierarkier formeligt pulveriseres i et sæt af 
horisontalt-sideordnede aperspektivistiske og relativistiske værdipunkter. Nielsen et tredie og helt afgørende sted:

\begin{abstract}
"Snarere end nihilisme er der altså tale om relativisme eller pluralisme. Eftersom der findes mange forskellige slags bevidstheder og synsvinkler, findes der ... også mange forskellige værdier./ Ja, der findes faktisk så mange forskellige værdier, at de ikke kan underordnes et alment forpligtende princip gældende for alle æstetiske objekter. Imidlertid bygger de fleste hidtidige æstetiske teoridanneler på en sådan absolutistisk forestilling om, at det kan lade sig gøre at sige noget grundlæggende om det værdifulde ved den klasse af objekter, man plejer at kalde æstetiske, så det kommer til at gælde for alle disse objekter.« (1968:50)
\end{abstract}

Hvad der her er under angreb er netop dén æestetiske tradition der historisk primært - og måske som den enste - har frembåret en sådan monolitisk og absolutistisk forståelse: modernismen. Og her særlig som denne traditions selvforståelse er blevet rationaliseret i modernisme-kritikken. Hvor den mest konsekvente og systematiske gennemføring har Adornos signatur. Hele forestillingen om kunstens udvikling som én historie afsat af én nødvendig tendens i det æstetiske materiale, der gør det muligt at tale om 'én international standard', og muligt at udstede 'en kanon af forbud' samt udpege præcis dét sted hvor materialet er på sit mest avancerede. Og hele forestillingen om en værdi-absolutisme under hvilken alt kan vurderes fra ét punkt, ét sæt af givne kriterier og indplaceres i ét hierarki. Det er hele dette forestillingskompleks der her anfægtes. ${ }^{3}$ Og det er samtidig præcis når dette absolutistiske og monolistiske forestillingskompleks problematiseres at modernismen geråder i krise. Modernismens krise indtræder nemlig - som bl.a. Fredric Jameson har formuleret det - når det pludselig bliver åbenlyst, at et bestemt værk, et bestemt forfatterskab, en bestemt stil »når alt kom til alt alligevel ikke var en absolut, ikke den endelig fundendte figuration af verdens sandhed, men kun ét kunstsprog blandt andre, kun en hylde med varker $i$ et helt svimlende bibliotek «. ${ }^{4}$ Den nye pluralisme og relativisme der ligger anslået omkring tidsskiftet $t a^{\prime}$ er således i central forstand ikke alene modernismens krise og endeligt. Men allerede i sin offensive positive formulering hinsides denne. ${ }^{5}$

Den her skitserede 'efter-moderne' relativistiske-pluralistiske impuls er den ene pointe den næunte traditionelle interpretation af den nye accept af massekulturen læser hen over. Den anden er at den tiltagende interesse for massekulturen også var kunstnerisk begrundet. Forankret - nemlig - i bestemte momenter af den xstetiske erfaring. Hvor visse kunstnere fandt afgørende affiniteter mellem på den ene side: den nye æstetik og den nye holdning den unge genera- 
tion repræsenterede. Og på den anden: de produktionsteknikker og æstetiske træk der lå indfældet $\mathrm{i}$ visse af massekulturens former. F.eks.: Konstruktionen af de fiktive universer som spilstrukturer. De sætstykkeagtige environments Handlingsforløbets og situationernes stiliserede skematiske karakter. De 'apsykologiske' skabeloner og figurernes anonymitet, fleksibilitet og rolleskift. Kommunikationen i betydningsflader i stedet for i -dybder osv. På samme måde som Nielsen medgav at han var fascineret af tegneserier fordi de oplevedes som modsvarende "et meget centralt punkt i min livs- og samtidsoplevelse: Betydningens indskrumpen $\ll{ }^{6}$

Denne bemærkelsesværdige konvergens mellem 'høj'- og 'lav'-kultur er netop ubegribelig for en traditionel opfattelse af de to kulturformer. Der læser dem efter model af en - væsentligst i valuative termer frembåret - dipolær og absolut modsætning. Og derfor kun kan se konvergensen i billedet af: degeneration, dekadence. Derimod bliver den begribelig ud fra en mere genuin og historisk anlagt synsvinkel på den totale kulturelle situation. Fredric Jameson har her i Reification and Utopia in Mass Culture korrekt påpeget, at den fra en historisk betragtning eneste form for 'høj'-kultur der kan siges at konstituere en modsætning til massekulturen er den højkulturproduktion som har været samtidig med denne. - De facto: Modernismen. Modernismen og massekulturen er således født ud af den samme historiske situation.

I dette privilegerede perspektiv bliver det pludselig muligt at begribe: hvorfor den hidtidigt fungerende grænsedragning mellem 'høj'og 'lav'-kulturen på visse strategiske punkter gennembrydes i æstetikken omkring tidsskriftet $t a$ '. Idet - nemlig - de to kulturformer her i et vist mål afsøger samme løsninger på samme grundlæggende problemer - og deri konvergerer. Og den nye kunstner-generations overgivelse af det tidligere centrale modernistiske ressistens-moment: subjektiviteten, der gør at man nu parallelt med massekulturen møder den tiltagende objektivering og afsubjektivisering på det sociale plan med en tilsvarende anonymisering og afpersonalisering i den kulturelle produktion, er blot ét moment af en sådan kulturel konvergens. Ligesom det i dette perspektiv bliver muligt at forstå tidsskriftet $t a$ ' som markerende en forløber for den senere postmodernistiske kultur og det postmoderne vilkår. Hvor de tradtionelle kulturelle demarkationslinier for alvor problematiseres og penetreres. Idet de forskellige kulturformer nu tilsyneladende i tiltagende grad udviser de samme reaktive tendenser på den fælles historiske, sociale og æstetiske situation. 


\section{Attituderelativismen-eller: „WHAT'S HAPPENING, $B A B Y$ ?"}

Opbruddet i den æstetiske situation og erfaring kobles hos en del af $t a^{\prime}$-gruppens medlemmer også direkte til et modsvarende opbrud i menneske-opfattelsen, subjekt-konceptionen. Mest udtalt hos HansJørgen Nielsen, der allerede i den indledende program-artikel i $t a$ ' 1 : "WHAT'S HAPENING, BABY?" $\mathrm{i}$ anslaget pointerer at de nye kunstneriske fænomener »kommer på tværs af den model, som den humanistisk-individualistiske tradition og senere modernismen har dannet sig af det menneskelige subjekt« $(1967,1: 2)$. Og den nye jegforståelse får måske tilsvarende sit mest manifeste æstetiske udtryk i Nielsens »læredigt om mig selv« der står som den ligeså programmatiske afslutning på $t a^{\prime}$ l:

laredigt om mig selv

jeg er jeg og jeg ved hvad jeg er og jeg er ikke foran jeg er bagefter og jeg er ikke folkelig jeg er eksklusiv og jeg er ikke optimist jeg er pessimist og jeg er ikke naiv jeg er sentimental og jeg er ikke objektiv jeg er subjektiv og jeg er ikke modernist jeg traditionalist og jeg er ikke normal jeg er basse og jeg er ikke spontan jeg er intellektuel og jeg er ikke socialist jeg er liberalist og jeg er ikke hel jeg er splittet og jeg er ikke for jeg er imod og jeg er ikke bag- efter jeg er foran og jeg er ikke eksklusiv jeg er folkelig og jeg er ikke pessimist jeg er optimist og jeg er ikke sentimental jeg er naiv og jeg er ikke subjektiv jeg er objektiv og jeg er ikke traditionalist jeg er modernist og jeg er ikke bøsse jeg er normal og jeg er ikke intellektuel jeg er spontan og jeg er ikke liberalist jeg er socialist og jeg er ikke splittet jeg er hel og jeg er ikke imod jeg er for og jeg ved hvad jeg er og jeg er jeg: nemlig

'Læredigtet' former sig som en gentagelses-struktur med tautologien som konstituerende figur. En figur der repeteres og permuteres i en række kvalitative personlige positionsbestemmelser som for hovedpartens vedkommende markerer væsentlige tematiseringer i sen60ernes kulturelle debat. Imidlertid folder og spejler digtet sig over sin egen midterakse. Således at sidste halvdel repetativt gennemspiller de diamentralt modsatte permutationer. Hvorved der opstår den komplekse struktur: at tautologierne modsiges af de diamentralt modsatte tautologier. Og da opbygningen i grammatiske parallelismer, i identiske syntaktiske repetitioner yderligere producerer en nivellerende effekt, idet de kvalitativt vidt forskellige udsagn ikke overeller under-ordnes, men sammenstilles i en parataktisk struktur hvor det ene udsagn ikke ophæver det andet, så kommer samtlige af de modstridende udsagn til at stå tilbage som lige gyldige. I gennem digtets tekstmaskineagtige kombinatorik gennemspiller 'jeget' såle- 
des en række kvalitativt forskellige positioner. For umiddelbart efter radikalt at dementere selvsamme positioner og indtage de dimentralt modsatte. Uden at jeg-konstitutionen dog deri anfægtes og uden jegidentiteten dermed underkastes tragisk splittelse, krise eller tab. Hvad det eneste éntydige udsagn der såvel indleder som afslutter digtet markerer: »Jeg ved hvad jeg er og jeg er jeg «. Der tilmed pointeres af systemets eneste asymetriske element i form af det efterstillede, subjektivt emfatiske: »nemlig «. Som signalerer at der her er tale om et konstitueret, selvbegrebet og selv-reflekterende subjekt.

Det er præcis en sådan menneske-konception og subjekt-konstitution Nielsen ser vokse frem i den unge generation og finder reflekteret i den samtidige kunst og kultur. Og det er præcis en sådan jegforståelse han positivt forsøger at lancere under termen 'attituderelativisme' i "WHAT'S HAPPENING, BABY?«. Der derved samtidig kommet til at stå som en art 'ATTITUDERELATIVISMENS MANIFEST'. Opbruddet i opfattelsen af det menneskelige subjekt bliver her formuleret som opgivelsen af forestillingen om jeget som autonom enhed. Som monadisk helhed. Som sluttet entydig identitet: Det sig selv bevidste punktuelle jeg. Til fordel for en oplosning i et helt felt af holdepunkter: »hvis forestillingen om et »jeg « herefter skal fastholdes må dette jeg fortolkes som noget multiplicerbart. Jeg er ... ikke mere jeg, men en hel række jeg'er« $(1967,1: 3)$. En forståelse der i Nielsen og den hvide Verden direkte formuleres som en "post-individualistisk betragtningsmåde« (1968:17). Opgivelsen af individualiteten betyder dog ikke samtidig at identiteten forlades. Blot at opfattelsen af dens struktur revideres. Således at jeget nu forstås i modellen af et »knippe fragmentariske funktioner« (15), »et helt spektrum af roller, som jeg frit glider ind og ud af og som til sammen er min 'personlighed' « (89).

Hele denne nye subjektforståelse sættes tillige i sammenhæng med en ombrydning i synsvinklen fra det enkelte, isolerede jeg til jeget i dets relation udadtil. Hvor mennesket »ikke mere defineres i dets unikke individualitet, men ved dets socialitet« (1967,1:3). En fokusforskydning i samtidig kunst og kultur Nielsen i Nielsen og den hvide verden profetisk forbinder til »et omsving af uoverskuelige dimensioner: Groft sagt fra individuel psykologi og psykoanalyse til fænomenologi og sociologi - fra jeg-bevidsthed til rollebevidsthed «(1968:17).

Selv om Nielsen senere modificerer og relativerer denne totale horisontalitet, pluralisme og attituderelativisme ved at formulere 'det aperspektivistiske jeg' som et jeg i en valgsituation, der ud fra den givne sociale sammenhæng vælger sine attituder og værdipunkter: 》Jeg må gøre et valg. Vælge verden. Min verden« (1968:23). Og deri 
- tværimod at afkaste - stadig sætter det central-perspektivistiske syn som gyldig forudsætning, på trods af alle radikale hævdelser af subjektets primære definition i socialiteten, for således nu blot på et ét-trinhøjere-niveau at reetablere 'det centrerede jeg'. Så er det alligevel svært andet end $i$ attituderelativismen at se en filosofi, en oplevelsesform og en model for subjektets konstitution der udgør en kimform og forløber for den senere under postmodernistisk teori så fejrede: decentrering af det tidligere centrerede subjekt, skizofrenien - subjektets død. Forstået som sammenbruddet for forestillingerne om monaden, den autonome individualitet, den unikke personlighed, den private identitet. Forestillinger der indtil dette tidspunkt ellers havde stået som fundamentale og altdominerende for menneskekonceptionen under den borgerlige æra - og ikke mindst for modernismens æstetik og ideologi. ${ }^{1}$

Det er denne overfor beskrevne attituderelativistiske menneskekonception og jeg-struktur Nielsen finder korrespondencer til i den samtidige kunst og kultur. Gennem hvad han med et centralt citat løftet fra John Cage kalder: »totalt felt, mangfoldighed uden brændpunkt«. Af Cage selv samme sted betegnet som 'vores ikke-renæssanceerfaringer'. En principiel horisontal betragtningsmåde Nielsen $b \stackrel{a}{-}$ de ser som noget helt centralt ved »dén sensibilitet, dét forandrede syn på jeg'et og omverdenen, som inderst inde er den psykologiske betingelse for en række af de kunstneriske fænomener, man konfronteres med i disse vigtige år « $(1967,1: 2)$, og for en lang række samtidige ungdomskulturelle fænomener: livsstil, massekultur, pigtrådsmusik og mode: »Det Cage kalder »totalt felt«, er i virkeligheden omridset af en ny form for enhedskultur. The Beatles: „Here there and everywhere" « $(1967,1: 4)$. En horisontalt sideordnende betragtningsmåde Nielsen forbinder såvel til Marshall McLuhans visioner om en 'simultan verden' og 'den globale landsby': „Vores samlede sensibilitet boltrer sig her $\mathrm{i}$ en kompleks og hele tiden foranderlig fornemmelse af samtidighed «(1968:88) som til Susan Sontags koncepter om 'One Culture' og 'The New Sensibility':'

\footnotetext{
"En ny sensibilitet hvor den skønhed, man kan finde $i$ en maskine, $j$ løsningen af et matematisk problem, i Beatles musik, $i$ en bog af Beckett, $i$ en smuk kjole eller i en skulptur af Claes Oldenburg, er lige så attråværdig og lige værdifuld. På tværs af gamle spaltninger og kulturkløfter er udviklingen af sig selv tilsyneladende ved at fremtvinge en ny form for enheds-kultur (1968:86)
}

Den ændrede subjekt-strukturering og den frembrydende horisontale betragtningsmåde forankres også flere steder direkte i forandringerne 
i den sociale virkelighed: I det nye medieteknologiske samfund. Efter en henvisning til netop Marshall McLuhan og hans teorier om 'the global village' og om eksplosionen i medierne, ekspansionen i den elektroniske teknologi som »en kolassal udvidelse af sindet... et kæmpemæssigt eksternt nervesystem« skriver Nielsen således i »WHAT'S HAPPENING, BABY?«:

"I dette samfund bombarderes man med indtryk og informationer fra alle vinkler og involveres uafladeligt på et utal af ofte indbyrdes modstridende niveauer, uden at man kan unddrage sig det. Og over for det krav om en uhyre fleksibilitet, man her konfronteres med, er en attituderelativisme af den beskevne art den eneste mulighed for at komme til at fungere fornuftigt i forhold til virkeligheden.« $(1967,1: 4)$

Attituderelativismen begrundes således her pragmatisk $\mathrm{i}$ forhold til en forandret social situation: som dén nye social-psykologi, dén nye sociale personligheds-type og dét nye oplevelsesberedskab, der er i stand til adækvat at møde omstillingskravene i en nu totalt fragmenteret og pulveriseret virkelighed. Thi en socialitet konstitueret af kulturel pluralitet, relativitet, disponibilitet, et oplevelsesfeltet sat af simultanitet, sideordning, mangfoldighed, fordrer nødvendigvis et fluktuerende, fleksibelt jeg. Som Nielsen her billedliggør det i en art dansk billigudgave af McLuhans 'globale Landsby':

"Et simultanpunkt:/I telefonen taler jeg med en ven i New York og samtidig overværer jeg i tv krigen i Vietnam, mens min kone skramler i køkkenet, og linie 10 kører forbi nede på gaden / /Et fortløbende bombardement af samtidig og indbyrdes ofte modstridende billeder, som man kun kan leve med ved at acceptere netop det modstridende og flydende, det relative.« (1968:105).

\section{Den taktiske virkeligheds-accept-eller: "Hr. Godot formoder jeg?}

I det hele taget synes der i og omkring tidsskriftet $t a$ ' at være en højtopdreven bevidsthed omkring en bestemt sammenhæng mellem: På den ene side frembruddet af en ny æstetik, en 'ny sensibilitet' en hel t ny virkelighedsoplevelse. Og på den anden: en ny social modalitet primært som denne rent udvendigt manifesterer sig i de innovative teknologier og medier der får deres brede samfundsmæssige gennemslag og tilsynekomst på netop dette tidspunkt. Et forhold Nielsen for så vidt allerede havde henledt opmærksomheden på i sin artikel i 'konkretistnummeret' af Vindrosen $(1966,3)$ året før $t a$ 's lancering. Hvor fremkomsten af 'konkret-poesien' og andre beslæg tede æstetiske 
fænomener blev sat i direkte forbindelse med det samtidige gennembrud for de nye massemedier, datamaskinen, informationsteorien og 'kommunikationsrevolutionen'. Som det f.eks. udmøntes i følgende karakteristiske udgangsreplik: "Hvor den hidtidige modernisme bl.a. kan ses som et produkt af den industrielle revolution kan konkretpoesien og beslælgtede fænomener bl.a. ses som et produkt af kommunikationsrevolutionen. / John Cage: Happy new ears! « (1966,3:19). En ny æstetisk bevidsthed og en ny medieteknologisk situation der igen sammenkoblet sættes i umiddelbar sammenhæng med et større epokalt ombrud i kulturen som helhed. 'En bevidsthedsmutation' -- hedder det ligefrem i efterskriftet til Eksempler.

Helt tilsvarende er også Peter Louis-Jensen inde på - og her $i$ direkte forlængelse af konstateringen af de traditionelle formers nye forføjbarhed og disponibilitet - at grundlaget for det skabende arbejde har ændret karakter »som følge af ændringer på det sociologiske plan«:

"Strukturændringerne i vort samfund er i det væsentligste sket på basis af en omfattende brug af massemedier som TV, radio, telestedet for vor direkte naturiagttagelser.. Der er tale om en total ændring i det kunstneriske felt. En revolution uden manifest, men med klart sigte.« (1967,1:12-3).

Og en revolution der - som Louis-Jensen antyder det - bl.a. resulterer i en sammenskridning af de traditionelle demarkationslinier mellem virkelighed og billede, oprindeligt og afledt, det repræsenterede og det repræsenterende. Efter den nye elektroniske medieteknologi er det nemlig »ikke mere muligt at skelne mellem »teknisk " og »menneskelig« virkelighed, mellem virkelighed af »primær«, naturlig art og virkelighed af "sekundær«, artificiel art. / Det er ét fedt i det elektroniske massekommunikationssamfund« (1967,1:3). Som det hedder i »WHAT'S HAPPENING, BABY?《 - når Nielsen ekkoer McLuhan.

For Nielsen afsætter dette at »en stor del af ens virkelighed udgøres af massemedier, hvor alt virkelig er substandsløse billeder og mønstre« en oplevelse af omverdenen som artificiel, syntetisk, betydningsflad. Verden som tv-skærm. Virkeligheden som en gigantisk billed-collage af et broget, adspredt billedmylder. Der i sidste instans skrider sammen i en selvophævende tomhed og hvidhed. Hvad Nielsen i sit 'selvforklarende' titelessay i Nielsen og den hvide verden bekender som sin personlige grundstemning: "I can see the whole room and there's nobody in it (1968:138). Selv om det samtidig pointeres at massemedierne snarere demonstrerer end determinerer 
forholdet hvorfor det også har gyldighed uden for disse. - 'Verden ifølge Nielsen':

\begin{abstract}
"Jeg kan ikke opleve den informationsstrøm af billeder, mønstre, images, den siure verdensmaskine udspyr, som andet end ret beset substandsløse... Jeg oplever ofte hele verden som flade syntetiske billeder, der vxider ud af en gigantisk maskine. Det er min private resonansbund for det hele.../ Billeder. Billede på billede på billede.../ ... En underlig spejlverden af billeder, hvor alle billeder er lige virkelige. Eller lige uvirkelige. Den slags begreber tæller ikke rigtig på den filmdug, hvor verden sker. / På den ene side lesslupne billeder af mere eller mindre syntetisk art. På den anden side også en vag fornemmelse af airkonditioneret mareridt. Af tid som står stille, mens et eller andet løbsk projekttionsapparat løber vildere og vildere. (137-8).
\end{abstract}

I denne overgribende vision af verden som en 'billed-verden', hvad Nielsen et andet sted ${ }^{1}$ også beskriver som en 'colusion', en forfalskning, en serie vilkårlige spilstrukturer og konventioner som hele kulturkredsen er underlagt, som vel at mærke sjældent erkendes i sin karakter af blot 'skue'-'spil', og hvor der tilsyneladende heller ikke gives nogen mere substantiel virkelighed hinsides 'billedvirkeligheden', i denne vision af verden synes Nielsen, attituderelativismen og tidsskriftet ta' at have påfaldende affinitet til senere såkaldt 'postmoderne teori' som denne udfolder sig omkring koncepter som: blændværker, hyperrealitet, simulakrum. ${ }^{2} \mathrm{Og}$ så meget des mere som den foreliggende virkelighed af Nielsen heri accepteres som den virkelighed der er, som virkeligheden. Som det fremgår når han $i$ afslutningen på »WHAT’S HAPPENING, BABY?« - der i Nielsen og den hvide verden er retituleret: "Hr. Godot formoder jeg? « - opsummerer den nye æstetiks helt centrale fællestræk i: »at virkeligheden ikke mere er et dæmonisk begreb, som det var for Gottfried Benn. Virkeligheden er simpelthen det, der foreligger horisonten rundt. / $\mathrm{Hr}$. Godot, formoder jeg? « (1968:12). Hvorved også verdens fundamentalt usammenhængende karakter og jegets fragmentering erkendes og accepteres som givet, uomgængeligt og afmystificeret livsvilkår: "Det splittede jeg og den splittede virkelighed er for den unge generation simpelthen jeget og virkeligheden - berøvet alle uholdbare myter « (1968:161). - Som det programmatisk fastslås i generationsantologien Eksempler. Afsættende en radikal ny social situation som på karakteristisk - og måske særlig 'post'-moderne - vis befinder sig hinsides splittelsens og fremmedgørelsens problematik. En virkeligheds-holdning der dog et andet sted ${ }^{3}$ straks revideres og re-formuleres som »en taktisk accept«: En - og her måske også særlig 'post'moderne - erkendelse af at virkeligheden 'bare' er en række konven- 
tioner og relative spil. Men samtidig en accept af at der ikke findes nogen 'anden' mere virkelig virkelighed bag denne 'pseudo-virkelighed': "Det er simpelthen... verdenen « (1968:16).

(Artiklen fortsættes i Kultur $\mathcal{E}^{\circ}$ Klasse 60, hvor også følger noter og bibliografi). 